\title{
Molecular epidemiology of canine norovirus in dogs from Portugal, 2007-2011
}

João Rodrigo Mesquita ${ }^{1,2^{*}}$ and Maria São José Nascimento ${ }^{1}$

\begin{abstract}
Background: Canine noroviruses (NoVs) have been recently described in south European countries and associated with outbreaks of diarrhea in kennels. Unlike human NoV which are known as an important cause of acute gastroenteritis, little is known about the role of canine NoV as pathogens in dogs as well as its epidemiological features.

Results: From 2007-2011, 256 stool samples were collected from dogs across Portugal and tested by RT-PCR for canine NoV. Viral fecal shedding was found to be 23\% (60/256). All sequences contained the GLPSG amino acid motif characteristic of the RNA-dependent RNA-polymerase gene of NoVs and had a high nucleotide identity (range 98\%-100\%) to the canine NoV first described in Portugal. The highest shedding rate was detected during the winter months.
\end{abstract}

Conclusions: This study shows that canine NoV infection is endemic in the dog population of Portugal. Peak shedding was detected in the winter months, a well-known epidemiologic feature of human NoV infections.

Keywords: Canine norovirus, Dog, Fecal shedding, Winter, Seasonality

\section{Background}

Noroviruses (NoV) are non-enveloped, single-stranded RNA viruses belonging to the genus Norovirus of the family Caliciviridae [1]. Until recently, NoV could be genetically classified into 5 genogroups (GI, GII, GIII, GIV and GV) with human NoV belonging to GI, GII, and GIV [1]. Human NoVs are the most frequent cause of outbreaks of acute gastroenteritis and the most common cause of sporadic enteric illness [2,3]. Infections occur year round but in temperate climates outbreaks show a seasonal peak activity during the winter [4]. Recently, NoVs were reported in dogs with acute gastroenteritis [5,6]. Canine NoV closely related to genogroup IV viruses was described in a diarrheic pup in Italy [5] and also caused an outbreak of diarrhea in a kennel in Greece [7]. A genetically different canine NoV was detected in dogs with diarrhea in Portugal [6]. Last year, we described an outbreak of gastroenteritis associated with canine NoV among kenneled dogs in Portugal,

\footnotetext{
* Correspondence: jmesquita@esav.jpv.pt

'Departamento de Ciências Biológicas, Laboratório de Microbiologia,

Universidade do Porto, Portugal, Rua Jorge Viterbo Ferreira, 228, Porto 4050-313, Portugal

${ }^{2}$ Secção de Ciências Veterinárias, Instituto Politécnico de Viseu, Quinta da Alagoa - Estrada de Nelas, Ranhados, Viseu 3500-606, Portugal
}

highlighting for the first time some epidemiological similarities between canine and human NoV outbreaks [8]. Despite the focus on the potential role as a pathogen in dogs, epidemiological features of canine $\mathrm{NoV}$ are not well described. Additionally, although a world-wide distribution of canine NoV has been suggested [9], the extent of geographical dissemination of canine NoV in different dog populations is unknown. In the present work, we tested fecal specimens from dogs collected from 2007 and 2011 in Portugal. Our data suggest seasonal variation of canine $\mathrm{NoV}$ infections similar to human NoV infections.

\section{Methods \\ Samples}

Between 2007 and 2011, a total of 256 fecal samples were collected from dogs (regardless of their health status) housed in a variety of facilities such as municipal dog pounds, non-profit dog rescue shelters, animal shops, veterinary hospitals and veterinary clinics across Portugal.

\section{RNA extraction and RT-PCR}

Stools were diluted (10\%) in phosphate-buffered saline, $\mathrm{pH}$ 7.2, and solids were removed by centrifugation at

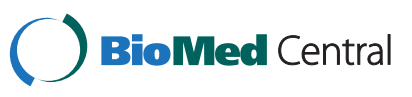


$8000 \mathrm{~g}$ for $5 \mathrm{~min}$. Viral nucleic acid was extracted from $140 \mu \mathrm{l}$ of each clarified stool suspension by the QIAamp viral RNA mini kit (Qiagen, Hilden, Germany), according to the manufacturers' instructions. Viral nucleic acid was tested for the presence of canine NoV by RT-PCR (Qiagen One-Step RT-PCR Kit) using the primers JV102 (5'-TGG GAT TCA ACA CAG CAGAG-3') and JV103 (5'-TGC GCA ATA GAG TTG ACCTG-3') targeting a small region of the RNA-dependent RNA-polymerase gene [6]. Briefly, $5 \mu \mathrm{l}$ of viral nucleic acid was added to an RT-PCR mix (Qiagen One-Step RT-PCR Kit) containing RNase-free water, Qiagen RT-PCR buffer (5x), dNTP mix (10 mM), Enzyme mix (RT and Taq), $100 \mathrm{mM}$ forward and reverse primer and RNase inhibitor (40 U). Cycling conditions consisted of reverse transcription for $30 \mathrm{~min}$ at $42^{\circ} \mathrm{C}$, activation of Taq polymerase for $15 \mathrm{~min}$ at $95^{\circ} \mathrm{C}, 40$ cycles of $1 \mathrm{~min}$ at $94^{\circ} \mathrm{C}, 1 \mathrm{~min}$ at $37^{\circ} \mathrm{C}$, and $1 \mathrm{~min}$ at $72^{\circ} \mathrm{C}$, followed by a final extension for $10 \mathrm{~min}$ at $72^{\circ} \mathrm{C}$.

\section{Sequencing and phylogenetic analysis}

RT-PCR products were separated by electrophoresis in a $1.5 \%$ agarose gel and visualized under UV after ethidium bromide staining. Appropriately sized bands (215 bp) were excised from the gel and purified with the QIAquick gel extraction kit (QIAGEN) and sequenced in both directions using the BigDye Terminator v1.1 Cycle Sequencing kit (PE Applied Biosystems, Foster City, CA, USA). Sequence editing and multiple alignments were performed with the BioEdit software package, version 2.1. Phylogenetic analysis was drawn by using TreeCon software with bootstrap analysis $(n=1,000)$, and the tree topology was inferred by using neighbor-joining.

\section{Results}

Sixty (23\%) of the 256 samples tested positive for canine NoV. Sequences from the 60 samples contained the GLPSG amino acid motif characteristic of NoV viral RNA-dependent RNA-polymerase. Sequence analysis showed a high nucleotide identity (range $98 \%-100 \%$ ) to the first canine NoV detected in Portugal, Viseu strain [6] (Figure 1).

From a total of 91 dogs tested in winter months, 33 (36\%) were found to be shedding canine NoV, whereas only $25 \%(21 / 84)$ and $7 \%(6 / 81)$ were shedding canine NoV in spring and autumn months, respectively (Figure 2). A chi-square test for homogeneity of proportions (SPSS 13.0, SPSS Inc., Chicago, IL, USA) showed that the percentage of positive samples in autumn, winter and spring months were significantly different $(\mathrm{p}<0.001)$.

\section{Discussion}

During a 4-year period 23\% of stools collected from dogs across Portugal tested positive for canine NoV. Compared to the prototype canine NoV (Viseu strain), all strains had a high identity at nucleotide (range $98 \%-100 \%$ ) and amino acid (100\%) levels. At the nucleotide level several strains from 2007, 2008 and 2009 had identical sequences to the Viseu strain. Interestingly, strains detected in 2010 had an identical sequence as strain 1026 collected in 2007 tempting us to speculate that strain 1026 might have emerged as a new genetic variant and prevailed through 2010 in the dog population. However, because only a small fragment of the genome was sequenced these conclusions should be interpreted with caution and additional sequence information from the capsid regions of the genome is required to confirm this hypothesis.

The mechanism how new NoV variants emerge is currently unknown. For human NoVs, the high genetic mutation rate [11], as well as viral antigen and host receptor interactions [12] have been suggested as potential contributors. Similar events could have taken place for canine $\mathrm{NoV}$ in the dog population.

Most canine NoV positive samples had been collected during winter months. Although no samples were collected during the summer months, our data show a peak of canine NoV activity in the colder months, an epidemiological feature typical of human NoV infections [13]. Additional studies with at least monthly sampling for several years are necessary for a more comprehensive analysis. The reason for human NoV seasonality remains unknown, but is believed to be a combination of complex multifactorial aspects that include environmental, host and virologic factors [14]. Changes in environmental conditions, such as humidity and temperature, are known to be associated with seasonality of viral diseases allowing for a winter predisposition [15]. The seasonality of rotavirus has been suggested to be due in part to the low relative humidity indoors during the cold periods, encouraging not only the persistence of infectious viruses on surfaces but also aerosolization of virus-laden dust particles [16]. Concerning NoV, it is known that cool and dry conditions are favorable for survival of infectious virus [17]. An increase in the number of canine $\mathrm{NoV}$ positive samples in the colder months might be associated with the overcrowding of kennels, a typical event in rainy and colder winter months where animals are more often kept indoors. Enteric virus transmission in dogs has been mentioned to be facilitated in large breeding colonies where hygiene is difficult to maintain and fecal contamination of the environment is at its maximum [18]. Moreover, seasonal variations in the host susceptibility to infections have also been suggested, possibly associated with changes in the animals' physiological status in winter [18]. Hence, more thorough kennel hygiene and disinfection procedures should be taken in the colder months when overcrowding is likely to 


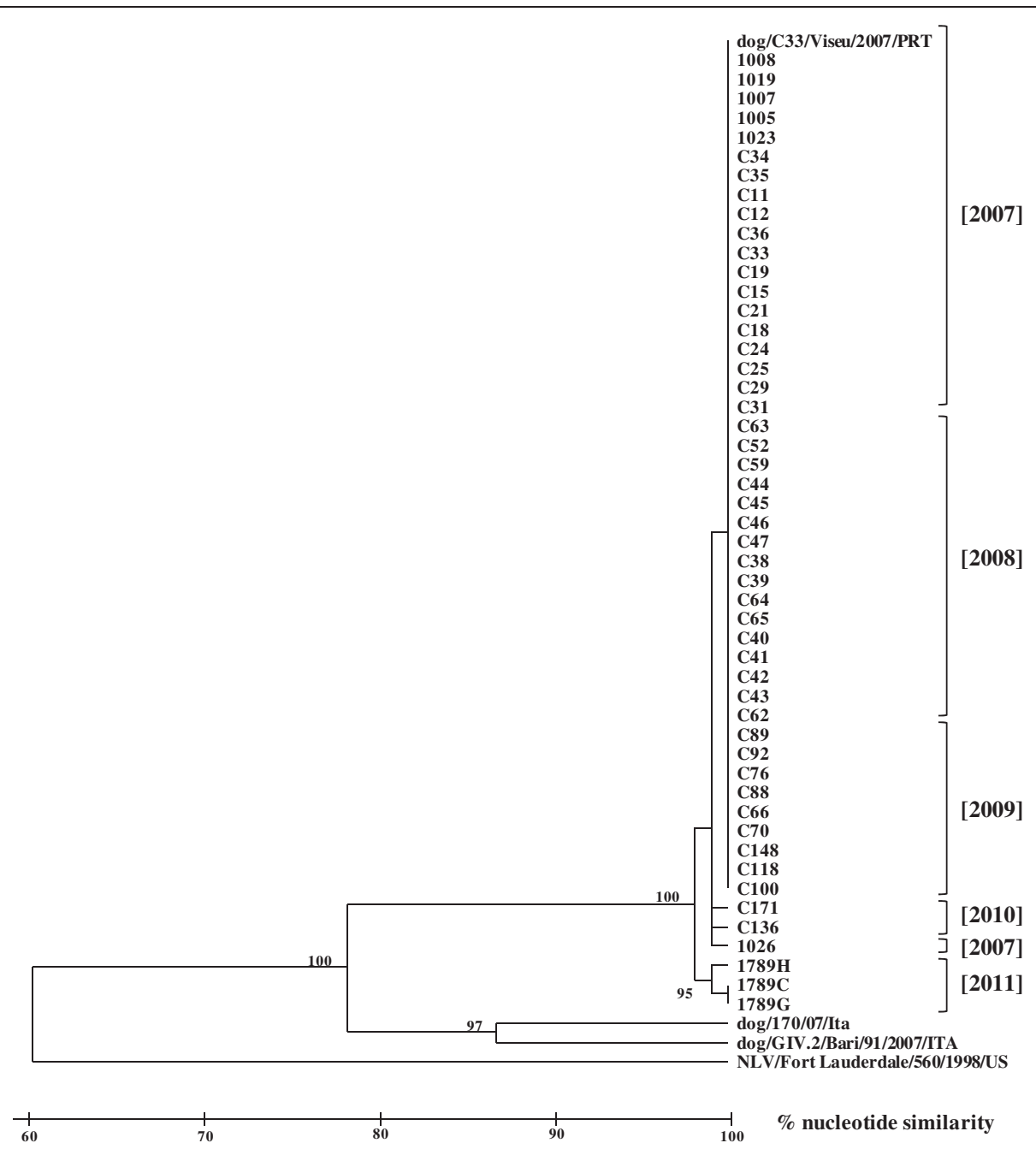

Figure 1 Phylogenetic tree of a 215-nt region of the RNA-dependent polymerase gene of one human genogroup IV strain NLV/Fort Lauderdale/560/1998/US (accession no: AF414426), the two canine noroviruses reported from Italy, dog/170/07/Ita (accession no: EU224456) and dog/GIV.2/Bari/91/2007/ITA (accession no: FJ875027), and the canine norovirus reported from Portugal dog/C33/Viseu/ 2007/PRT (accession no: GQ443611). Sample collection years are in brackets.

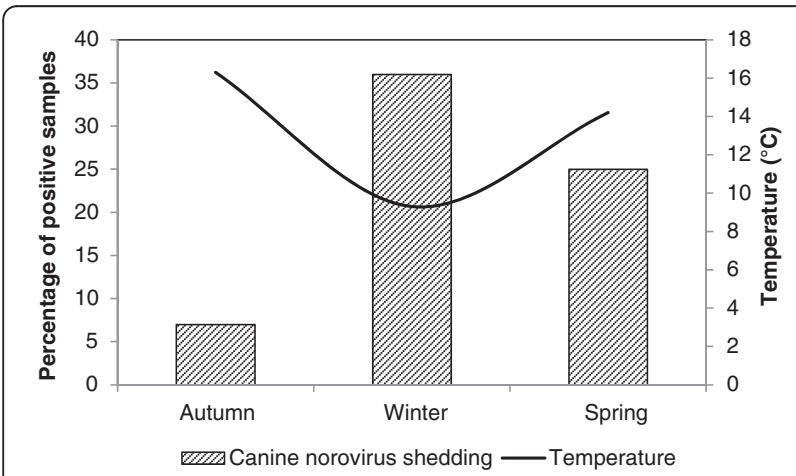

Figure 2 Seasonal variation of canine norovirus fecal shedding in dogs of Portugal from 2007 to 2011 and mean temperature in Portugal from 2000-2009 [10]. occur, in order to decrease the chances for transmission of canine NoV.

\section{Conclusions}

This study shows that canine NoV infection is endemic in the dog population of Portugal. Peak shedding was detected in the winter months, a well-known epidemiologic feature of human NoV infections. This interesting finding is preliminary and requires to be further explored. Overall, the present work constitutes an important contribution to the knowledge of the epidemiology of canine NoV infection, still at its infancy. 


\section{Acknowledgements}

We thank Dr. Jan Vinjé at the Centers for Disease Control for his support and critical reading of the manuscript. The study was supported by FEDER funds through Programa Operacional Factores de Competividade - COMPETE, by National funding through FCT - Fundação para a Ciência e a Tecnologia (project PTDC/CVT/113218/2009) and by grant SFRH/BD/45407/2008 to J.R.M. from Fundação para a Ciência e a Tecnologia.

\section{Authors' contributions}

JRM and MSJN conceived and designed the study, drafted and revised the manuscript. JRM performed the laboratory assays. Both authors approved the final manuscript.

Received: 4 March 2012 Accepted: 9 July 2012

Published: 9 July 2012

\section{References}

1. Clarke IN, Estes MK, Green KY, Hansman GS, Knowles NJ, Koopmans MK, Matson DO, Meyers G, Neill JD, Radford A, Smith AW, Studdert MJ, Thiel H-J, Vinjé J: Caliciviridae, Virus taxonomy: the classification and nomenclature of viruses. In The ninth report of the International Committee on Taxonomy of Viruses. Edited by King AMQ, Adams MJ, Carstens EB, Lefkowitz EJ. Walham, MA, USA: Springer-Verlag; 2012:977-986.

2. Glass RI, Parashar UD, Estes MK: Norovirus gastroenteritis. N Engl J Med 2009, 361:1776-1785.

3. Patel MM, Hall AJ, Vinjé J, Parashar UD: Noroviruses: a comprehensive review. J Clin Virol 2009, 44:1-8.

4. Siebenga JJ, Vennema H, Zheng DP, Vinjé J, Lee BE, Pang XL, Ho EC, Lim W, Choudekar A, Broor S, Halperin T, Rasool NB, Hewitt J, Greening GE, Jin M, Duan ZJ, Lucero Y, O'Ryan M, Hoehne M, Schreier E, Ratcliff RM, White PA, Iritani N, Reuter G, Koopmans M: Norovirus illness is a global problem: emergence and spread of norovirus Gll.4 variants, 2001-2007. J Infect Dis 2009, 200:802-812.

5. Martella V, Lorusso E, Decaro N, Elia G, Radogna A, D'Abramo M, Desario C, Cavalli A, Corrente M, Camero M, Germinario CA, Banyai K, Di Martino B, Marsilio F, Carmichael LE, Buonavoglia C: Detection and molecular characterization of a canine norovirus. Emerg Infect Dis 2008, 14:1306-1308.

6. Mesquita JR, Barclay L, Nascimento MSJ, Vinjé J: Novel Norovirus in Dogs with Diarrhea. Emerg Infect Dis 2010, 16:980-982.

7. Ntafis V, Xylouri E, Radogna A, Buonavoglia C, Martella V: An outbreak of canine norovirus infection in young dogs. $J$ Clin Microbiol 2010, 48:2605-2608.

8. Mesquita JR, Nascimento MSJ: Gastroenteritis outbreak associated with faecal shedding of Canine Norovirus in a Portuguese Kennel following introduction of imported dogs from Russia. Transbound Emerg Dis 2011, doi:10.1111/j.1865-1682.2011.01284.x.

9. MacLachlan NJ, Dubovi EJ (Eds): Fenner's Veterinary Virology. London: Academic Press; 2011.

10. IM: Análise Climatológica da década 2000-2009. Ministério da Ciência, Tecnologia e Ensino Superior. 2011:1-18.

11. Gallimore Cl, Iturriza-Gomara M, Xerry J, Adigwe J, Gray JJ: Inter-seasonal diversity of norovirus genotypes: emergence and selection of virus variants. Arch Virol 2007, 152:1295-1303.

12. Huang $P$, Farkas T, Zhong W, Tan M, Thornton S, Morrow AL, Jiang X: Norovirus and histo-blood group antigens: demonstration of a wide spectrum of strain specificities and classification of two major binding groups among multiple binding patterns. J Virol 2005, 79:6714-6722.

13. Rohayem J: Norovirus seasonality and the potential impact of climate change. Clin Microbiol Infect 2009, 15:524-527.

14. Rydell GE, Kindberg E, Larson G, Svensson L: Susceptibility to winter vomiting disease: a sweet matter. Rev Med Virol 2011, 21:370-382.

15. Chew FT, Doraisingham S, Ling AE, Kumarasinghe G, Lee BW: Seasona trends of viral respiratory tract infections in the tropics. Epidemiol Infect 1998, 121:121-128.

16. Rzezutka A, Cook N: Survival of human enteric viruses in the environment and food. FEMS Microbiol Rev 2004, 28:441-453.

17. Lopman B, Armstrong B, Atchison C, Gray JJ: Host, weather and virological factors drive norovirus epidemiology: time-series analysis of laboratory surveillance data in England and Wales. PLoS One 2009, 24:e6671.
18. Murphy F, Gibbs E, Horzinek M, Studdert MJ: Veterinary virology. London: San Diego; 1999.

\section{doi:10.1186/1746-6148-8-107}

Cite this article as: Mesquita and Nascimento: Molecular epidemiology of canine norovirus in dogs from Portugal, 2007-2011. BMC Veterinary Research 2012 8:107.

\section{Submit your next manuscript to BioMed Central and take full advantage of:}

- Convenient online submission

- Thorough peer review

- No space constraints or color figure charges

- Immediate publication on acceptance

- Inclusion in PubMed, CAS, Scopus and Google Scholar

- Research which is freely available for redistribution

Submit your manuscript at www.biomedcentral.com/submit
Biomed Central 